\title{
The Case Of Edward Revere Osler
}

\author{
PH Starling
}

\begin{abstract}
In today's military medical environment interoperability is a regular occurrence. During the First World War a small group of eminent medical men from England and America combined their skills to endeavour to save the life of the son of another eminent physician.
\end{abstract}

\section{Introduction}

Edward Revere Osler was born on the 28th December 1895, the son of the eminent physician, Sir William Osler and Grace Revere Osler. At his birth Edward was described as 'a strong and durable specimen' (1). He was the great, great grandson of Paul Revere, a Boston silversmith and engraver who, dressed as an Indian, took part in the Boston Tea Party but who would gain everlasting fame as the American patriot who during the American Revolution in 1775 , rode all night to warn of the approach of the British (2). Paul Revere also had some connections to medicine; he made false teeth and an advertisement in an edition of the Boston Gazette of July 1770, assured the readership that his replacement teeth were 'of real use in speaking and eating'.

At the outbreak of the first world war Grace and Revere were in Canada and immediately sailed for England, to join William Osler at Oxford, where he was Regius Professor of Medicine and living at 13 Norham Gardens, Oxford.

Revere (as he was known) was about to start as an undergraduate at Christ Church College. Although he would be old enough to enlist he really had no interest in matters military, preferring to spend his time fishing, swimming and boating. Once at the college he eventually joined the Officer's Training Corps and his attitude to the war began to change; he felt that he ought to 'do his bit'. One consideration was some sort of medical work. He eventually dropped out of Christ Church and using some of his family connections joined the Canadian Red Cross, Duchess of Connaught Hospital, at Cliveden, as assistant Quartermaster.

One guest at the Osler's Oxford home during the Spring of 1915 was another eminent Canadian doctor, John McCrae, on leave from the front. He was followed in May by another old friend of the family, the American neurosurgeon, Harvey Cushing.

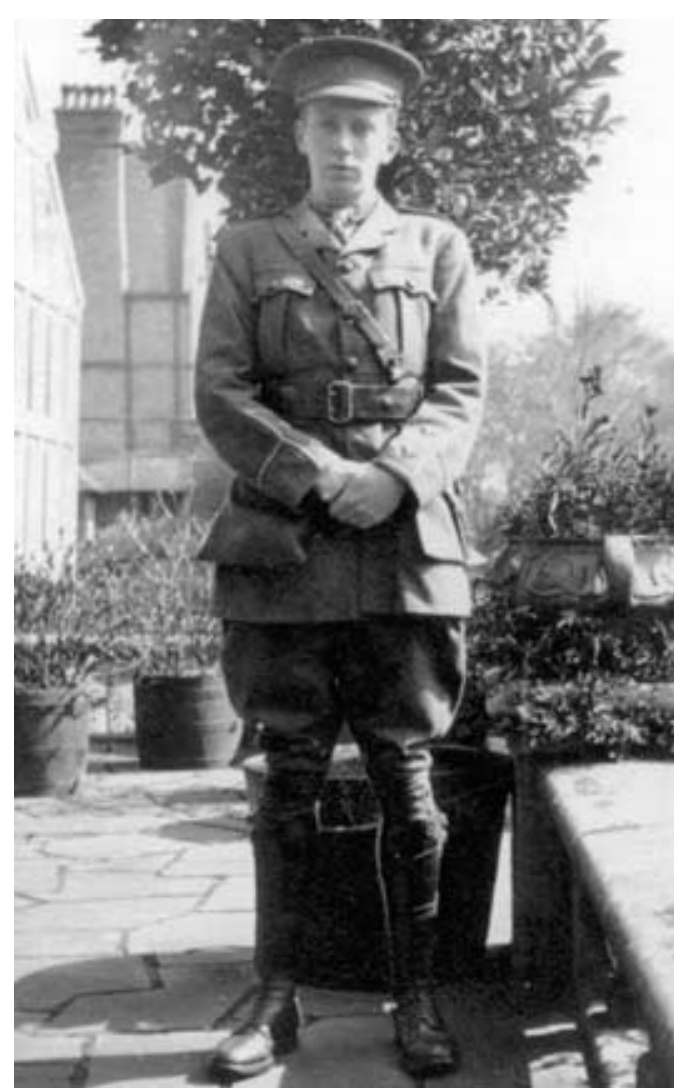

Edward Revere Osler 1915

By kind permission The Library of the History of Medicine McGill University, Montreal, Canada.

The McGill hospital unit, including Revere, went to France in the summer of 1915 and set themselves up at DannesCamiers, on the coast. It was a quiet time for the hospital, with very few patients coming their way. This had a profound effect on Revere and his conscience began to bother him. He felt that perhaps he should be more actively employed. As a consequence he considered a move to a field ambulance (3).

\section{To War}

By November, with the McGill hospital closed, Revere became even more disillusioned with life behind the lines and longed for a transfer. Eventually the inactivity and his inability to organise a transfer to a field ambulance became too much for him, so he decided to join the Royal Artillery. Even this took several months to organise, which kept him from the Somme offensive of the summer of 1916. It was eventually October of that year before he finally found himself at the front,
Aldershot, GU12 5RQ. 


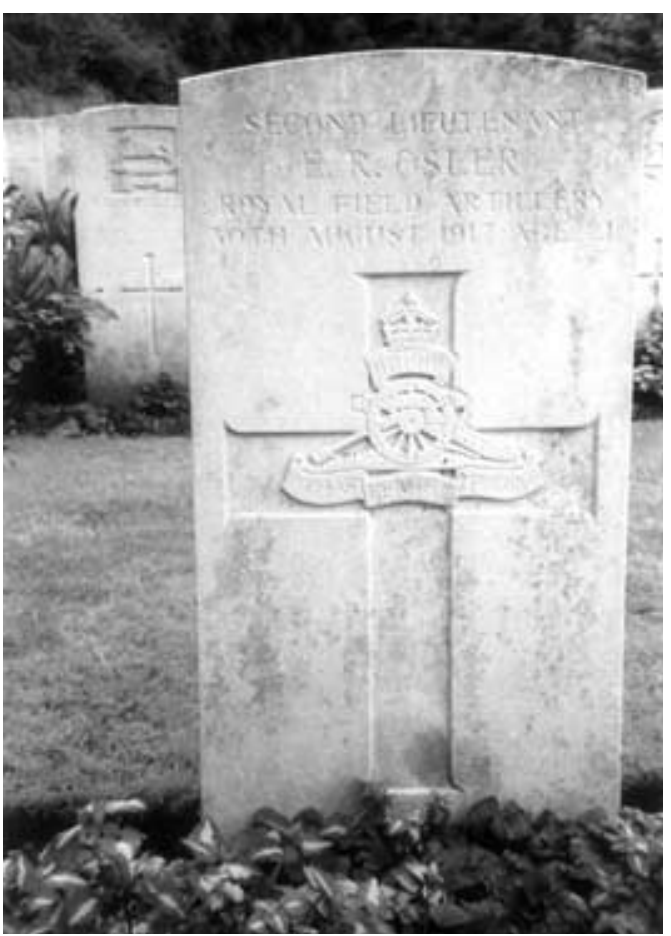

The grave of Edward Revere Osler in Dozinghem Military Cemetery.

as a Second Lieutenant in A Battery, 59th Brigade, Royal Field Artillery. His record of the transfer notes his qualities as being a good horseman and being accustomed to mechanical drawing and the using of tools' (4).

Revere spent his 21 st birthday in Belgium and on his birthday his parents transferred $£ 6,500$ into his bank account to allow him some financial independence on his return from the war. Both William and Grace worried constantly about their son and Grace secretly felt she would never see him again. They wrote to him constantly and worried if there was no immediate reply. Eventually in May 1917 Revere came home on leave. William was amazed at the transformation of Revere into a man, complete with moustache.

After ten days of fishing, reading and enjoying the company of his parents, he returned to Belgium, secretly hoping that he would get a 'blighty' wound, which would take him out of the hell which was the Western Front. In mid August he was slightly gassed but soon recovered.

\section{The Wounding}

On Wednesday 29th August 1917, A Battery was preparing to move its $18 \mathrm{pdr}$ guns forward to a new position at Hindenburg Farm. This involved filling in shell holes and preparing a track up to the farm. At about $5 \mathrm{pm}$, Osler, in company with Major Batchelor, the Battery Commander and Captain Lym Taverner, the Battery Captain, were standing watching about a dozen men filling in a shell hole, when without warning a German 4.2in shell landed amongst them (5). Major Batchelor, seven men and Revere were wounded. Revere received shrapnel wounds to the chest, abdomen and thigh. $\mathrm{He}$ was quickly carried into a gun pit by Major Batchelor (despite his own wounds) and Captain Taverner. After having his wounds dressed Revere was put on a stretcher and carried to 131 Field Ambulance Advanced Dressing Station located at Canada Farm (6) and eventually to Essex Farm, and finally by ambulance to 47 Casualty Clearing Station, located at Dozinghem, arriving there at $7.00 \mathrm{pm}$. Major Batchelor, his own wounds in need of treatment, accompanied him in the ambulance to Dozinghem. The staff at 47 CCS got a message off to Harvey Cushing who was at 46 CCS located at Mendingham, who immediately made the journey by motor ambulance, through the pouring rain. When he arrived he found Revere in extreme shock and no time could be lost if they were to save him and send him home to his parents. As Revere drifted in and out of conciousness he was gladdened to see his father's old friend, Harvey Cushing standing over him and as Cushing later wrote, 'smiled and said, "So glad you're here" , (7).

\section{All Was Lost}

Other eminent American surgeons, all friends of his father, rushed to Dozinghem to offer assistance, one of whom was George Washington Crile (8) an expert on blood transfusion working at $17 \mathrm{CCS}$, located in Remy Sidings. Crile was given the message at $10.20 \mathrm{pm}$ and travelled the short distance to Dozinghem in the company of $\mathrm{Lt}$ Eisenbrey (9). Crile took with him his transfusion apparatus and immediately began to replace some of the precious blood that had already been lost. By the time the transfusion was completed it was almost midnight and the surgery commenced.

Crile gives his account of Osler's treatment and subsequent death.

Brewer (10), Cushing \& I were in consultation, the splendid Durrach (11) in charge. The long marquee tent was quiet and dim; the end was fast approaching. The boy's features were serene and a faint smile illuminated his face when he was told that his father's American friends were there.

Durrach and Brewer operated, Harvey held his pulse and I continued the transfusion......... Large rents were found in the colon, much blood in the chest and a large wound in the thigh..... Obviously all was lost (12).

A second transfusion was given which did cause some improvement (13) but this was short lived and despite the attention from such experts in their field, he died the next morning. He was buried in a grave lined with Alder branches, wrapped in a blanket and covered in a Union Jack. Buglers sounded the Last Post and the American Surgeons who had fought so hard to save 
him now mourned him. How would his great, great grandfather have felt, seeing the flag he had fought to rid from his country, now covering his young descendant?

Cushing sent a telegram to Osler telling him his son was gravely wounded, not having the heart to tell him he was dead but Osler feared the truth. Osler immediately made plans to travel to Belgium but the War Office urged caution and advised the Oslers to await further word. They were waiting with packed bags when the telegram with the notification of his death arrived. This was followed over the next few days by numerous letters of condolence, from friends and from his battery officers, in which Sir William was told of a recommendation for a Military Cross (14), which, sadly, did not materialise. Brewer and Cushing also wrote giving details of the surgery and their efforts to save Revere.

For the Oslers there was not any major show of mourning, their life had to go on but they secretly grieved for their son, especially Sir William who was prone to bouts of weeping. He busied himself with his work but it is said that Sir William Osler never recovered from the loss of his son. He eventually died of Influenza two years later but some say he died of a broken heart.

Revere Osler is buried in Dozinghem Military Cemetery plot 4, row F. His parents would eventually be sent his British War Medal and Victory Medal and his bronze memorial plaque.

\section{Acknowledgements}

The author would like to thank the following for their help during the research into Edward Revere Osler:

Colonel David E Lounsbury MD, United States Army Medical Corps, who first brought this story to my notice.

Mr James Banks, Director of the Crile Archives, Parma Ohio for his assistance with the career of GW Crile.
Professor William C Hannigan MD PhD, Clinical Professor of Neurological Surgery and Paediatrics, University of Illinois.

Mrs Carol Hobbs, Head Librarian Defence Medical Services Training Centre.

Pamela Miller, Acting Head, Osler Library of the History of Medicine, McGill University, Montreal for her great help and permission to reproduce the photographs.

The Western Front Association for permission to use the map.

\section{References}

1. Bliss M. William Osler, A Life in Medicine. 1999, Oxford University Press.

2. Hibbert C. Redcoats and Rebels, The War for America 1779-1781. 2001, Classic Penguin.

3. ibid

4. Edward Revere Osler file. Public Record Office WO 338233677.

5. War Diary 59th Artillery Brigade. Public Record Office WO 951802 . The month of August 1917 is missing.

6. War Diary 131 Field Ambulance. Public Record Office WO 952550.

7. Cushing H. From a Surgeon's fournal. 1936, Constable and Co Ltd. Cushing was the Consultant Neurosurgeon to the American Expeditionary Force (AEF) and a long time friend of the family.

8. George Washington Crile was born on 11th November 1864. Served in the Spanish American war as a Brigade Surgeon Major. In 1906 he performed the first human blood transfusion. In WW1 he was Chief Consultant General Surgeon to the AEF.

9. War Diary 17th CCS. Public Record Office WO 95 343.

10. George Emerson Brewer. Original Director and Chief of Surgery at Base Hospital No 2, then 1st Corps.

11. Lt Col William Durrach. Assistant Consultant in General Surgery to 1 st Army.

12. Crile G (Ed). George Crile an Autobiography. Vol. 1. 1947, Lippincott Company.

13. Letter from Cushing to Susan dated 30 August 1917. Osler Library, McGill University.

14. Letter from Major VA Batchelor RA to Sir William Osler dated 1 September 1917. Osler Library McGill University.

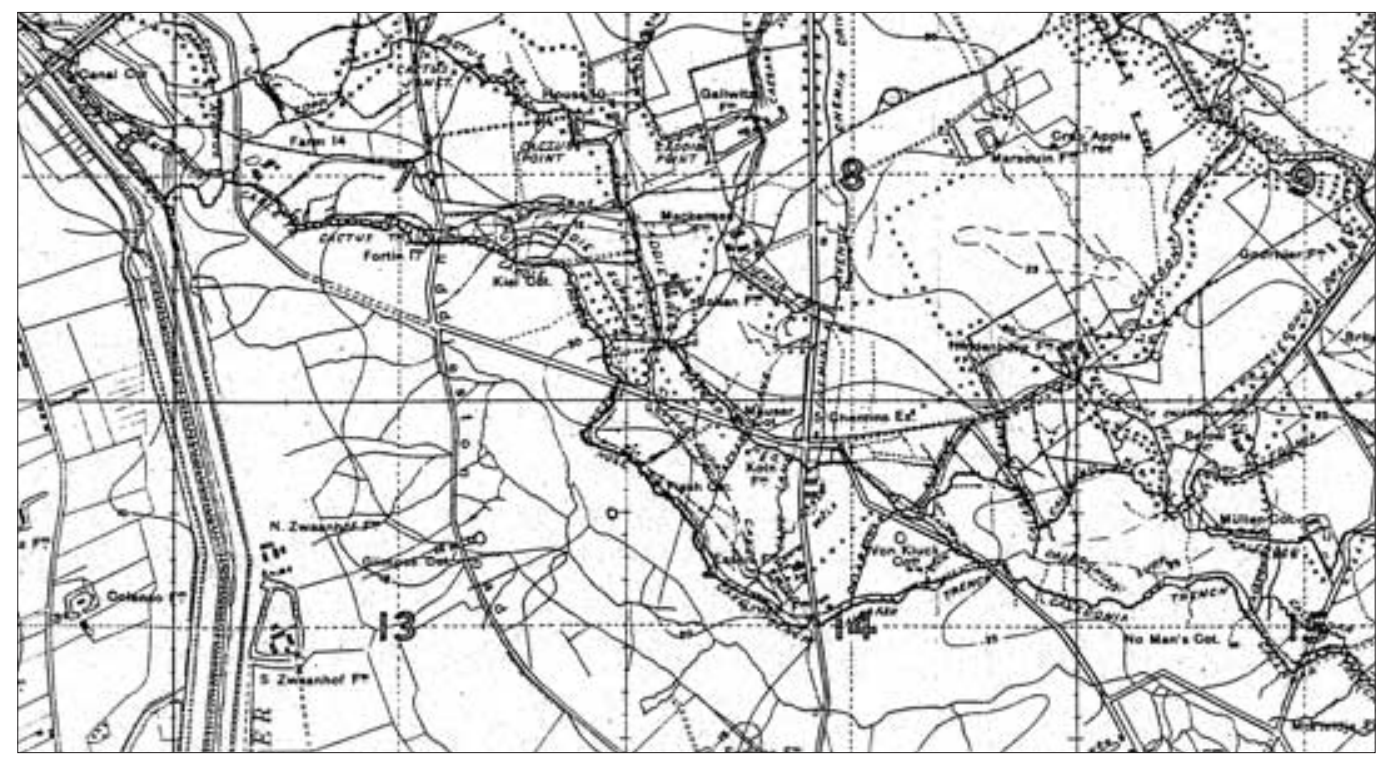

Copy of the trench map of the area North East of Ypres, showing Hindenberg Farm and the area in which Osler was wounded. By kind permission of the Western Front Association. 